\title{
Is fertility of hybrids enough to conclude that the two oysters Crassostrea gigas and Crassostrea angulata are the same species?
}

\author{
Arnaud Huvet ${ }^{\text {a,b }}$, André Gérard ${ }^{\text {a }}$, Christophe Ledu a , Pascal Phélipot a , Serge Heurtebise a, \\ Pierre Boudry ${ }^{\mathrm{a}, *}$
}

a Laboratoire de Génétique et Pathologie, Ifremer, BP 133, 17390 La Tremblade, France

' Laboratoire de Physiologie des Invertébrés, Ifremer, BP 70, 29280 Plouzané, France

Received 4 July 2001; accepted 12 November 2001

\begin{abstract}
The distinction of the two cupped oysters Crassostrea gigas (Thunberg, 1793) and Crassostrea angulata (Lamark, 1819) into two species was chiefly due to their differing geographical distributions, $C$. gigas being present in Asia and C. angulata in Europe. Today it is commonly accepted that $C$. angulata and $C$. gigas are a single species according to morphological, genetic and F1 hybridization data. However, the demonstration of the fertility of their hybrids and the absence of any reproductive isolation remained to be investigated. Consequently, we studied the fertility of hybrids and sperm competition by performing three different experiments and producing G1 and G2 hybrid progenies between wild populations of $C$. angulata and $C$. gigas. Progenies showed very close developmental yields, at 24 hours after fertilization, according to dam taxa suggesting a strong maternal transmission of oocyte quality, but no reproductive isolation was observed between the two taxa. Significant decreases of developmental yields were noticed in C. angulata females with sperm competition, most probably due to early larval mortality. The fertility of hybrids $C$. angulata $\times C$. gigas was demonstrated, which is further evidence that they are the same species. To definitively state the precise taxonomic classification of $C$. angulata and $C$. gigas, further studies are needed to (i) identify geographical zones where these taxa are in contact and (ii) assess their level of hybridization in these zones. (C) 2002 Ifremer/CNRS/Inra/Cemagref/Éditions scientifiques et médicales Elsevier SAS. All rights reserved.
\end{abstract}

\section{Résumé}

La fertilité entre individus hybrides est-elle suffisante pour conclure que les huîtres Crassostrea gigas et Crassostrea angulata relèvent de la même espèce ? La définition en deux espèces de Crassostrea gigas (Thunberg, 1793) et Crassostrea angulata (Lamark, 1819) était essentiellement basée sur l'apparente disparité de leur répartition géographique, $C$. gigas ayant été décrite en Asie et $C$. angulata en Europe. L'existence d'une seule et même espèce regroupant $C$. angulata et $C$. gigas est maintenant communément acceptée basée sur leurs similitudes morphologiques et génétiques et sur les données d'hybridation expérimentale de première génération. Cependant, la démonstration de la fertilité des hybrides et l'absence d'isolement reproductif restaient à étudier. Pour ce faire, trois séries de croisements expérimentaux de première $(\mathrm{G} 1)$ et seconde $(\mathrm{G} 2)$ générations ont été réalisés entre deux populations sauvages d'huîtres creuses $C$. angulata et $C$. gigas. Les descendances ont montré des taux de développement, estimés 24 heures après fécondation, corrélés au taxon maternel suggérant un fort effet maternel sur la qualité des ovocytes mais aucun isolement reproductif post-zygotique n'a été observé. Cependant, une diminution significative des taux de développement a été notée sur les femelles $C$. angulata, en condition de compétition spermatique, probablement due à des mortalités larvaires précoces. La fertilité des hybrides $C$. angulata $\times$ C gigas a été démontrée. Ceci constitue une preuve supplémentaire de leur appartenance à une seule même espèce. Pour définitivement conclure sur le statut taxonomique de C. angulata et $C$. gigas, des études complémentaires sont nécessaires pour (1) identifier les zones géographiques où ces taxons sont en contact et (2) évaluer leur niveau d'hybridation dans ces zones. (C) 2002 Ifremer/CNRS/Inra/Cemagref/Éditions scientifiques et médicales Elsevier SAS. Tous droits réservés.

Keywords: Hybridization; Controlled crosses; Fertility; Developmental yields of larvae; Crassostrea gigas; Crassostrea angulata

\footnotetext{
* Corresponding author.

E-mail address: pboudry@ifremer.fr (P. Boudry).
} 


\section{Introduction}

Many studies have reported attempted interspecific hybridization in oysters, particularly within the genus Crassostrea. Gaffney and Allen (1993) described the difficulties of such work: the ambiguities in the classification of oysters, the necessity to asses the gamete quality and the need for confirmation of the hybrid status of offspring using genetic markers. All attempts to produce first-generation (G1) hybrids between the Portuguese oyster Crassostrea angulata and the Pacific oyster Crassostrea gigas have been successful (Imai and Sakai, 1961; Menzel, 1968, 1971, 1974, 1987; Numachi, 1977; Gaffney and Allen, 1993), which was attributed to their close genetic similarity (Gaffney and Allen, 1993).

Crassostrea gigas and $C$. angulata were first described by Thunberg (1793) and Lamark (1819) respectively. The main reason for their distinction into two different species was their apparently separated geographical distribution; C. angulata was described in Europe and C. gigas in Asia. However, following morphological comparison (Ranson, 1948) and allozyme data (Mathers et al., 1974; Buroker et al., 1979; Mattiucci and Villani, 1983), the different authors concluded that there was only a single species. Their division into two subspecies was proposed by Menzel (1974). Significant phenotypic differences between the two taxa were observed. Crassostrea gigas shows a superior production yield in the natural environment in France (Héral, 1986; Héral et al., 1986; Bougrier et al., 1986; Parache, 1989), as its growth was twice that of the Portuguese oyster (Bougrier et al., 1986). Differences were also revealed in terms of their ecophysiological characteristics (His, 1972; Goulletquer et al., 1999). Furthermore, genetic differences were observed between the two taxa. Karyotype analyses highlighted the close genetic similarity of these two taxa in comparison with other cupped oyster species (Leitão et al., 1999a). However, differences between C. angulata and C. gigas were observed, notably for chromosome 7 (Leitão et al., 1999b). Two studies on the mitochondrial cytochrome oxidase subunit I (COI) gene (O'Foighil et al., 1998; Boudry et al., 1998) demonstrated a clear genetic difference between the two taxa. Indeed, the estimation in nucleotide divergence $(5.26 \%)$ of the cytochrome oxydase gene (COI) allowed the dating of the divergence between C. angulata and $C$. gigas to 1 to 2 million years and revealed the smallest genetic distance compared to those estimated between other Crassostrea species (O'Foighil et al., 1998). This divergence is also low compared to those observed for COI between other marine invertebrate species (e.g., 25\% between four species of copepods (RochaOlivares et al., 2001) and 20\% between two 'sister species' or subspecies of lobsters (Sarver et al., 1998). Studies of $C$. angulata and $C$. gigas on the COI gene (O'Foighil et al., 1998; Boudry et al., 1998) also offered an explanation for their separated geographical distribution, which supported the hypothesis of the introduction of $C$. angulata from Asia (and more precisely Taiwan) to the Portuguese coast during the 16th century. This hypothesis and the close genetic identity between the two cupped oysters were confirmed by a recent study using three microsatellite markers (Huvet et al., 2000). A significant but low genetic differentiation was revealed between $C$. angulata and $C$. gigas populations. A two-fold higher genetic differentiation was observed between populations of the different taxa than between populations within each taxa (Huvet et al., 2000).

The biological species concept, described by Mayr (1942), stated that species are groups of populations effectively or potentially able to cross among themselves. This concept emphasises reproductive isolation as the main discriminator of species, even when they are brought into contact in nature. This concept still acknowledges the occasional production of hybrids, or even hybrid zones, since hybridization does not disintegrate the genetic integrity of species as a whole (O'Brien and Mayr, 1991). For example, in mussels, Mytilus edulis, M. galloprovincialis and $M$. trossulus are recognized as three different species because genetically and morphologically different entities persist in the wild, despite high migratory flow (Koehn, 1991) and hybridization (Cousteau et al., 1991; Inoue et al., 1997; Daguin et al., 2001). Furthermore, lower viability of hybrids was experimentally shown at early larval stages (Beaumont et al., 1993; Bierne, in press).

In this concept, subspecies are considered as genetically distinguishable groups under conditions of allopatry but still ordinarily reproductively compatible (Mayr, 1970; O'Brien and Mayr, 1991). Clearly, elucidating such topics requires the study of hybridization both under experimental and natural conditions.

Concerning C. gigas and C. angulata, hybrids have been reported to be viable and to spawn when sexually mature (Menzel, 1974). Although normal meiosis in F1 hybrids and normal mitosis in F2 embryos were observed, larvae were not successfully reared (Menzel, 1974). Numachi (1966) performed rearing of $\mathrm{F} 2$ progenies, but they did not survive to settlement. As a consequence, it was not yet known if hybrids were fully fertile and F2 fully viable. Until now, no available studies directly assess the possibility of postzygotic reproductive barriers between $C$. angulata and $C$. gigas. The pre-zygotic stage was recently examined by assessing competition between $C$. gigas and $C$. angulata male gametes on female $C$. gigas and $C$. angulata oocytes. Molecular analysis of six-hour-old embryos showed no evidence of preferential fertilization between gametes from the same taxa, which suggested the absence of reproductive barriers at this stage (Huvet et al., 2001).

As a consequence, it was of great interest to investigate reproductive barriers at later stages and, more specifically, the fertility of hybrids between $C$. gigas and $C$. angulata. Here we report the production of G1 and G2 progenies in a total of 68 controlled crosses. We wished to test, under controlled experimental conditions, to what extent postzygotic barriers could separate these two taxa. 
Table 1

Controlled crosses of the first generation (G1) and second generation with sperm competition (G2C) experiments, and their mean developmental yield (\%) estimated at 24 hours (mean \pm standard error) with statistical tests, using the Least Square Difference, LSD.

\begin{tabular}{|c|c|c|c|c|c|c|}
\hline $\begin{array}{l}\text { Type of cross } \\
\text { females } \times \text { males }\end{array}$ & $\begin{array}{l}\text { Number of } \\
\text { replicates }\end{array}$ & $\begin{array}{l}\text { Number of parents } \\
\text { females } \times \text { males }\end{array}$ & $\begin{array}{l}\text { Mean developmental } \\
\text { yield }(\%)\end{array}$ & $\mathrm{F}$ & $\mathrm{P}$ & LSD \\
\hline \multicolumn{7}{|l|}{ G1 } \\
\hline GEN $\times$ GEN & 2 & $21 \mathrm{GEN} \times 10 \mathrm{GEN}$ & $77 \pm 3$ & & & $\mathrm{~A}$ \\
\hline $\mathrm{GEN} \times \mathrm{FLO}$ & 2 & $21 \mathrm{FLO} \times 15 \mathrm{FLO}$ & $66 \pm 2$ & 54.01 & 0.001 & A \\
\hline $\mathrm{FLO} \times \mathrm{GEN}$ & 2 & $21 \mathrm{FLO} \times 10 \mathrm{GEN}$ & $40 \pm 3$ & & $* *$ & $\mathrm{~B}$ \\
\hline $\mathrm{FLO} \times \mathrm{FLO}$ & 2 & $21 \mathrm{FLO} \times 15 \mathrm{FLO}$ & $45 \pm 1$ & & & $\mathrm{~B}$ \\
\hline \multicolumn{7}{|l|}{ G2C } \\
\hline $\mathrm{GG} \times \mathrm{GG}$ & 3 & $10 \mathrm{GG} \times 10 \mathrm{GG}$ & $41 \pm 6$ & & & A \\
\hline $\mathrm{AA} \times \mathrm{AA}$ & 3 & $10 \mathrm{AA} \times 10 \mathrm{AA}$ & $12 \pm 4$ & & & $\mathrm{~B}$ \\
\hline $\mathrm{AA} \times \mathrm{GG}$ & 3 & $10 \mathrm{AA} \times 10 \mathrm{GG}$ & $11 \pm 2$ & & & $\mathrm{~B}$ \\
\hline $\mathrm{GG} \times \mathrm{AA}$ & 3 & $10 \mathrm{GG} \times 10 \mathrm{AA}$ & $13 \pm 3$ & 171.60 & $<0.001$ & $\mathrm{~B}$ \\
\hline $\mathrm{GG} \times(1 / 2 \mathrm{AA}+1 / 2 \mathrm{GG})$ & 3 & $10 \mathrm{GG} \times(10 \mathrm{GG}+10 \mathrm{AA})$ & $12 \pm 2$ & 0 & $* * *$ & $\mathrm{~B}$ \\
\hline $\mathrm{AA} \times(1 / 2 \mathrm{AA}+1 / 2 \mathrm{GG})$ & 3 & $10 \mathrm{AA} \times(10 \mathrm{GG}+10 \mathrm{AA})$ & $0.4 \pm 0.3$ & & & $\mathrm{C}$ \\
\hline
\end{tabular}

GEN: French $C$. gigas population; FLO: Spanish $C$. angulata population. GG: pure $C$. gigas; AA: pure $C$. angulata; AG: hybrid of $C$. angulata G0 females and $C$. gigas G0 males; and GA: hybrid of $C$. gigas G0 females and $C$. angulata G0 males. ** significant at the $P<0.01$ level; $* * *$ significant at the $P<0.001$ level.

GG $\times$ GG means that oocytes from GG females were mixed with sperm from GG males; GG $\times(1 / 2$ AA $+1 / 2$ GG) means that oocytes from GG females were mixed with sperm from GG and AA males at a balanced ratio under the same final concentration that the crosses without sperm competition.

\section{Material and methods}

\subsection{Parental oysters $(G 0)$}

Wild oysters were collected from two locations along the Atlantic coast of Europe. A C. angulata population (FLO) was sampled in Canio Sancti Pietri in Spain (Cadix, $36^{\circ} 25^{\prime} \mathrm{N}, 6^{\circ} 08^{\prime} \mathrm{W}$ ), and a $C$. gigas population (GEN) from the Seudre Estuary (Marennes Oléron, $45^{\circ} 50^{\prime} \mathrm{N}$, $1^{\circ} 06^{\prime} \mathrm{W}$ ), one of the major areas for oyster farming in France. The classification of these oysters was confirmed by Polymerase Chain Reaction-Restriction Fragment Length Polymorphism (PCR-RFLP) analysis on a fragment of the mitochondrial COI gene as described in Boudry et al. (1998).

\subsection{Crosses}

\subsubsection{Experiment $G 1$}

Two replicates of four crosses were performed (Table 1). Abbreviations for G1 progenies are as follows: GG: pure $C$. gigas; AA: pure $C$. angulata; AG: hybrid of $C$. angulata $\mathrm{G} 0$ females and $C$. gigas $\mathrm{G} 0$ males; and GA: hybrid of $C$. gigas G0 females and $C$. angulata $\mathrm{G} 0$ males.

\subsubsection{Experiment $G 2$ Competition (G2C)}

One-year-old animals (ten females and ten males), from the previous experiment G1, were chosen at random and used as parents. Six types of crosses were performed in triplicate: two intra-crosses, two inter-crosses and two crosses with sperm competition (Table 1).

\subsubsection{Experiment G2 Fertility $(G 2 F)$}

This third experiment was done with two-year-old G1 animals (ten females and ten males). Twelve different types of crosses were performed: (i) within and between hybrids and parental types (with two replicates), and (ii) the same six crosses as the second experiment G2C (with three replicates) (Table 2).

All these crosses were made using the same procedure. Sperm was collected by stripping the gonads and diluting with seawater. The concentration of spermatozoa was estimated using Thoma slides (numeration slide with engraved grooves, $3 \mathrm{~mm}^{2}, 0.1 \mathrm{~mm}$ depth) coupled to an image processing system (Samba Technologies, Marcoussis, France). Oocytes of females of each type were then collected using the same procedure, and counted using Mallassez slides (numeration slide with engraved grooves, $5 \mathrm{~mm}^{2}, 0.1 \mathrm{~mm}$ depth). For all pools of females, oocytes were distributed in each fertilization beaker and then fertilised separately by a pool of males (ratio: 100 spermatozoa per oocyte).

\subsection{Fertilization rates and developmental yields}

Six hours after fertilization, embryos from each cross of the G2F experiment were collected by sieving and fixed with glucosamine-acetate buffer. Nuclear DNA was stained with $0.5 \mu \mathrm{g} . \mathrm{ml}^{-1}$ of Hoechst 33258 as described in Desrosiers et al. (1993). The fertilization rates were given by the ratio between number of developed embryos and the total number of embryos, including non-developed embryos and non-fertilized oocytes.

In all experiments (G1, G2C and G2F), 24 hours after fertilization, larvae were collected by sieving. The number 
Table 2

Controlled crosses of the second generation (G2F) experiment and their mean fertilization and developmental yield (\%) (mean \pm standard error), and settlement $(\%)$.

\begin{tabular}{lllll}
\hline Type of cross 10 females $\times 10$ males & Number of replicates & Mean fertilization $(\%)$ & Mean developmental yield $(\%)$ & Settlement $(\%)$ \\
\hline GG $\times$ GG & 3 & $88 \pm 1$ & $82 \pm 13$ & 32 \\
$\mathrm{AA} \times \mathrm{AA}$ & 3 & $64 \pm 1$ & $53 \pm 3$ & 30 \\
$\mathrm{AA} \times \mathrm{GG}$ & 3 & $64 \pm 15$ & $54 \pm 11$ & - \\
$\mathrm{GG} \times \mathrm{AA}$ & 3 & $80 \pm 2$ & $79 \pm 3$ & - \\
$\mathrm{GG} \times(1 / 2 \mathrm{AA}+1 / 2 \mathrm{GG})$ & 3 & $88 \pm 2$ & $76 \pm 8$ & - \\
$\mathrm{AA} \times(1 / 2 \mathrm{AA}+1 / 2 \mathrm{GG})$ & 3 & $62 \pm 3$ & $44 \pm 3$ & $53 \pm 3$ \\
$\mathrm{AA} \times \mathrm{AG}$ & 2 & $60 \pm 1$ & $52 \pm 11$ & 23 \\
$\mathrm{AA} \times \mathrm{GA}$ & 2 & $63 \pm 1$ & $53 \pm 1$ & 32 \\
$\mathrm{AG} \times \mathrm{AA}$ & 2 & $56 \pm 2$ & $52 \pm 1$ & 30 \\
$\mathrm{AG} \times \mathrm{AG}$ & 2 & $53 \pm 4$ & $57 \pm 1$ & 24 \\
$\mathrm{AG} \times \mathrm{GA}$ & 2 & $67 \pm 3$ & $50 \pm 2$ & 17 \\
$\mathrm{AG} \times \mathrm{GG}$ & 2 & $60 \pm 4$ & $71 \pm 1$ & 27 \\
$\mathrm{GA} \times \mathrm{AA}$ & 2 & $79 \pm 4$ & $69 \pm 8$ & 17 \\
$\mathrm{GA} \times \mathrm{AG}$ & 2 & $82 \pm 0.1$ & $79 \pm 6$ & 37 \\
$\mathrm{GA} \times \mathrm{GA}$ & 2 & $88 \pm 1$ & $57 \pm 2$ & 37 \\
$\mathrm{GA} \times \mathrm{GG}$ & 2 & $74 \pm 1$ & $82 \pm 3$ & 18 \\
$\mathrm{GG} \times \mathrm{AG}$ & 2 & $87 \pm 1$ & $77 \pm 0.2$ & 31 \\
$\mathrm{GG} \times \mathrm{GA}$ & 2 & $85 \pm 1$ & 10 \\
\hline
\end{tabular}

GG: pure $C$. gigas; AA: pure $C$. angulata; AG: hybrid of $C$. angulata $\mathrm{G} 0$ females and $C$. gigas $\mathrm{G} 0$ males; and GA: hybrid of $C$. gigas G0 females and C. angulata G0 males; -: samples not reared after larval stage.

GG $\times$ GG mean that oocytes from $10 \mathrm{GG}$ females were mixed with sperm from $10 \mathrm{GG}$ males; $\mathrm{GG} \times(1 / 2 \mathrm{AA}+1 / 2 \mathrm{GG})$ mean that oocytes from $10 \mathrm{GG}$ females were mixed with sperm from $10 \mathrm{GG}$ and $10 \mathrm{AA}$ males at a balanced ratio under the same final concentration that the crosses without sperm competition.

of developed D larvae were counted (Cell counter, three replicates), which gave the developmental yields when compared to the total number of oocytes used at the fertilization step. As such, developmental yield combines fertilization success and early viability.

\subsection{Larval rearing}

Only the crosses of the G1 and G2F experiments were reared until larval settlement. Rearing of larvae from crosses with sperm competition (G2C) was not performed because we focused only on fertilization rates in these crosses. Larvae were reared in glass-reinforced ployester (GRP) tanks filled with seawater (salinity 32, temperature $23 \pm 1{ }^{\circ} \mathrm{C}$ ) and were fed with Isochrysis galbana and Chaetoceros puminum (30 cells. $\mu \mathrm{l}^{-1}$ of each species). Every 48 hours, the larvae were collected by sieving and three samples were counted (Cell counter) and measured (Profile projector, Nikon). Density was progressively reduced by discarding a part of the population but without any selective sieving.

\subsection{Settlement}

When pediveliger larvae appeared, they were sieved on $200 \mu \mathrm{M}$ mesh and then settled on cultch (Walne, 1974) in raceways (sea water temperature $21^{\circ} \mathrm{C}$, salinity 32). Estimations of successful settlement were made at day 35 in crosses of the G2F experiment. The number of oysters was estimated by weighing an exact number of oysters (1 000) and the total spat of each cross.

\subsection{Data analysis}

Since the number of oocytes per studied batch was the same in all the crosses studied, all the statistical analyses could be done with analysis of variance using SYSTAT 9.0 by SPCC Inc., under the general model procedure.

Developmental yields (DY) were statistically analyzed from the three counts at the D larvae stage. Batch and cross (sperm competition vs. partitioned or parental type: $C$. angulata vs. C. gigas vs. hybrid) effects were tested according to a nested ANOVA using the following model:

$\mathrm{DY}=$ cross + cross $($ batch $)+\varepsilon$ with $\varepsilon$ the residual value.

ANOVAs were performed to compare all the developmental yields (DY) in the $\mathrm{G} 1$ and $\mathrm{G} 2 \mathrm{C}$ experiments. In the G2C and G2F experiments, developmental yields were also tested between partitioned crosses and crosses with sperm competition. Non-nested ANOVAs were performed to compare developmental yields in the G2F experiment according to the parental taxa of each cross. Finally, larval size was also tested between crosses with ANOVA.

In order to determine which pairs of means differ significantly, multiple comparisons were made using the least significant difference pairwise multiple comparison test using SYSTAT 9.0. This procedure was used in the comparison of developmental yields in the G1 and G2C 
experiments, and also in the G2F experiment according to the parental type of each cross.

\section{Results}

\subsection{Experiment G1 (first generation)}

The results allowed the comparison of performances among G0 progenies (i.e., pure $C$. angulata, pure $C$. gigas and hybrids) on developmental yields and larval growth. The developmental yields were $77 \%$ for pure $C$. gigas $(\mathrm{GG})$, $45 \%$ for pure C. angulata (AA), $66 \%$ for GA hybrids and $40 \%$ for AG hybrids (Table 1). The statistical test showed a significant difference between the four progenies, the GG and GA progenies having significantly higher developmental yields than the AG and AA ones ( $\mathrm{F}=54.01 ; P=0.001)$. However, no significant differences appeared in larval size between crosses, as for example at day 22 when pediveliger larvae appeared, their mean sizes were 304, 306, 306 and $316 \mu \mathrm{m}$ for AA, GG, GA and AG respectively $(\mathrm{F}=2.069$; $P=0.105)$.

\subsection{Experiment $G 2 C$ (second generation, competition)}

Mean developmental yields (DY) and standarddeviations in $\mathrm{G} 2 \mathrm{C}$ crosses are given in Table 1. The best rate (41\%) was obtained in the pure C. gigas cross and was significantly higher than the results of the other crosses ( $\mathrm{F}=171.60 ; P<0.001)$. The two hybrid crosses, the pure C. angulata cross and the cross with sperm competition on C. gigas females gave very close results, around $12 \%$, which were not significantly different. The cross with sperm competition on $C$. angulata females showed the lowest DY, less than $1 \%$. A significant effect appeared between batches (Sum of squares $=8556 ; \mathrm{F}=17.11 ; P<0.001$ ), but this only explained a small proportion of the total variance considering the observed effect between cross types (sum of squares $=85791 ; \mathrm{F}=171.60 ; P<0.001)$.

The developmental yields of crosses with sperm competition were significantly lower than all partitioned crosses $(\mathrm{F}=225.28$ and $357.5 ; P<0.001$ respectively on $C$. gigas and $C$. angulata females).

\subsection{Experiment $G 2 F$ (second generation, fertility)}

Table 2 gives the fertilization rates and development yields of each cross of G2F experiment. The fertilization rates ranged from $53-88.5 \%$ (mean value $72.4 \%$ ), which was 1.13 times higher than developmental yields (from 44-82\%; mean value $63.3 \%$ ).

The development rates were clearly higher in the G2F experiment (from 44-82\%) than in the G2C experiment (from $0.4-41 \%$ ). However, the hierarchy of these results was consistent in the two experiments, and their linear regression was significant $(\mathrm{F}=12.6, P=0.003)$.
No significant reduction of developmental yields appeared in sperm competition with the GG females $(F=2.60$; $P=0.124$ ) but a significant decrease was noticed with the AA females (sum of squares $=2151 ; \mathrm{F}=32.78 ; P<0.001$ ) when spermatozoa of both taxa are mixed together. A significant batch effect was revealed in statistical comparisons with the crosses on AA females, explaining a small proportion of the total variance (Sum of squares $=506$; $\mathrm{F}=7.57 ; P<0.001)$. Whatever the female taxa, no reduction of fertilization rates was observed between partitioned crosses (84\% and $64 \%$ on C. gigas and C. angulata females respectively) and crosses with sperm competition (87\% and $62 \%$ on $C$. gigas and C. angulata females respectively).

The developmental yields were averaged over crosses according to maternal or paternal type of each cross (Fig. 1). No significant differences appeared when developmental yields were averaged across the paternal type $(F=0.375$, $P=0.771$, Fig. 2), whereas significant hierarchical results appeared when they were averaged across the maternal type (F $=73.34, P<0.001$, Fig. 2). Based on the number of $\mathrm{D}$ larvae counted at 24 hours (DY), the four types of crosses (from females GG, GA, AG and AA) can be divided into three groups, incorporating crosses from $\mathrm{AA}$ and $\mathrm{AG}$ females, which had a mean DY of $52.7 \%$, significantly lower than in the crosses from GA (mean DY $=68.9 \%$ ) and GG females (mean DY $=80.2 \%$ ). In the same way, grouping developmental results of $\mathrm{G} 2$ progenies from types of $\mathrm{G} 0$ parents showed significant differences between crosses from C. angulata $(52 \pm 5 \%)$ and C. gigas $\mathrm{G} 0$ females $(75 \pm 9 \%$, $\mathrm{F}=160.77, P<0.001)$, whereas no differences appeared between crosses from $C$. angulata $(60 \pm 11 \%)$ and $C$. gigas G0 males $(67 \pm 15 \%, \mathrm{~F}=0.01, P=0.92)$.

Settlement was estimated for G2F crosses (Table 2) and values ranged from $10-37 \%$. The mean settlement percentage for crosses between parental types was $31.3 \%$ whereas it was $28.8 \%$ and $23.7 \%$ for crosses between hybrids and back-crosses respectively. It is not possible to test for the significance of these percentage because no replication was made.

\section{Discussion}

The reproductive barriers between two taxa can act at two different levels, pre- and post-zygotic. Only a few cases of pre-zygotic reproductive isolation have been reported in marine organisms with external fertilization (McCartney et al., 2000). Consequently, post-zygotic reproductive barriers to interspecific hybridization are to be expected in marine organisms. In oysters, normal fertilization success followed by subsequent abortive larval development has been reported in several interspecific crosses between Crassostrea species (for review see Gaffney and Allen, 1993). No pre-zygotic reproductive barriers to hybridization between C. gigas and C. angulata have been revealed experimentally (Gaffney and Allen, 1993; Huvet et al., 2001). Hence, a 

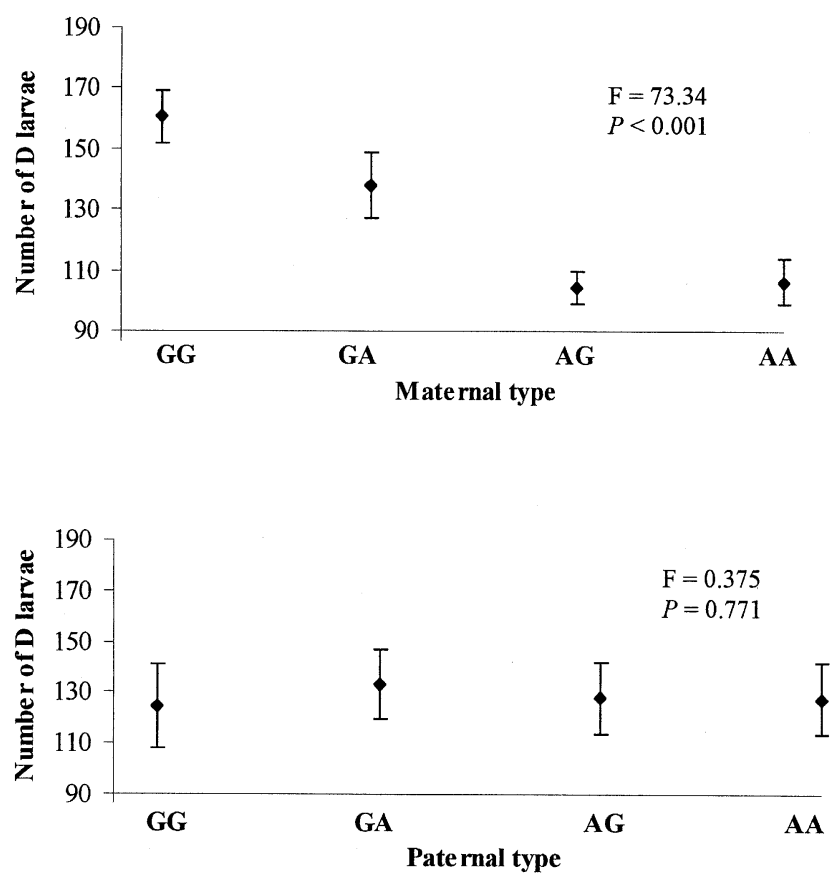

Fig. 1. Mean number of D larvae (counted 24 hours after fertilization to estimate the developmental yield) in crosses of the second generation G2F experiment (three counts per cross) according to the maternal or paternal types of each cross.

consistent analysis of post-zygotic barriers required the demonstration of the fertility of their hybrids. This experimental demonstration, together with the study of reproductive pattern when both taxa are in contact, are necessary to understand the evolutionary processes in putative wild sympatric zones.

As previously reported (Imai and Sakai, 1961; Menzel, 1974, 1986; Gaffney and Allen, 1993), the viability of hybrids between $C$. angulata and $C$. gigas is confirmed by our results with the G1 progenies. The $\mathrm{G} 2$ progenies (from the G2F experiment) showed good results in terms of fertilization rates, developmental yields, and settlement rates. These appeared normal in comparison with values usually observed in the La Tremblade hatchery (Robert and Gérard, 1999). G1 hybrids are therefore effectively fertile and G2 progenies are viable (reared successfully to more than one year of age). This is the first evidence of $C$. angulata $\times C$. gigas hybrid fertility. The present finding is a major criterion in favor of a single species grouping for $C$. angulata and $C$. gigas. Consequently, hybrids are to be expected in the wild, in geographical zones where the taxa are in contact. Indeed, the introduction of $C$. gigas into France since 1970 (Grizel and Héral, 1991) and its increasing production in Southern Europe provide the opportunity of such a contact zone between the two taxa. Up to now, only limited mixture of the two taxa have been observed in some populations introduced into Europe (Boudry et al., 1998; Huvet et al., 2000). The evolution of such contact between the taxa could lead to (i) extinction of one of the two taxa; (ii) stable coexistence with hybridization leading to the mix of the two genomes; or (iii) reinforcement of pre-mating isolation and speciation. Microgeographic and temporal studies of the genetic composition of these populations are therefore needed to understand the outcome of contact zones between the taxa.

The developmental yields were clearly higher in the G2F experiment than in the $\mathrm{G} 1$ and $\mathrm{G} 2 \mathrm{C}$ experiments. This could be due to differences in gamete quality between progenitors. However, the results showed the same hierarchy and appeared qualitatively congruent. Indeed, whatever the experiment, the highest reproductive success was always shown in the pure $C$. gigas crosses which could indicate a better general quality of the $C$. gigas gametes over $C$. angulata ones. The possible existence of natural spawning asynchrony could be considered as an explanation. This was suspected from chronological series, from 1950 to 2000, of larvae sampling in the Marennes Oléron basin (P. Soletchnik, pers. comm.), but should be considered with caution because the taxa were not present simultaneously in this area (presence of $C$. angulata from 1950 to 1970 and $C$. gigas from 1970 to 2000).

When the developmental yields were compared using all partitioned crosses, two significant clusters were shown. G2 progenies from pure $C$. angulata females displayed similar results in terms of developmental yields, as did G2 progenies from pure $C$. gigas females. This suggests a strong maternal transmission of oocyte quality, through at least two generations. In the same way, Eversole (1997) showed that the gametogenesis pattern of hybrid progenies between two close species of clam, Mercenaria mercenaria and Mercenaria campechiensis was similar to the pattern of the dam species.

A significant decrease of developmental yields was observed in the G2C crosses when sperm of both taxa were mixed together. This was more emphasized with the $C$. angulata females (30 times lower) than with $C$. gigas females (three times lower). The decrease of developmental yields with sperm competition might be more emphasized with $C$. angulata oocytes because of their supposed lower quality. Only a poorer fertilization or a higher death rate of embryos during the first 24 hours can explain this decrease. To confirm these observations, the same crosses were made in the G2F experiment with estimations of fertilization and developmental yields. With sperm competition on $C$. angulata females, the developmental yields also showed a significant decrease in comparison to partitioned crosses whereas this was not the case with $C$. gigas females. Furthermore, this difference was not observed with fertilization rates, suggesting early death of embryos rather than lower fertilization. It is possible that the mixing of sperm of the two taxa increases polyspermy. In our data however, no significant polyspermy was observed in embryos with the staining technique, and based on the results of Gérard (1998) with C. gigas, we would expect less than $10 \%$ polyspermy at the sperm concentration used in this study. Furthermore, significant polyspermy was only observed in 
C. virginica when the ratio of sperm-eggs exceeded 1000:1 (Alliegro and Wright, 1983). As these results are preliminary, further studies are needed to understand the biological phenomena leading to the increase of early death of embryos in conditions of sperm competition, which could be viewed as a kind of restriction to gene flow between populations of the two taxa.

\section{Conclusion}

Our present results show that Crassostrea angulata $\times$ Crassostrea gigas hybrids are fully fertile and no reproductive isolation is observed between the two taxa, which is further proof of the existence of a single species. Together with allozyme (Mathers et al., 1974; Buroker et al., 1979; Mattiucci and Villani, 1983) and morphological data (Ranson, 1948), these findings establish the very close relationship between these two taxa. However, small genetic differences were observed in karyotype analyses (ThiriotQuiévreux, 1984; Leitão et al., 1999a,b) and in molecular analyses (O'Foighil et al., 1998; Boudry et al., 1998; Huvet et al., 2000). These are not in disagreement with the definition of a single species. A similar case exists within the species Crassostrea virginica, where a mitochondrial marker revealed a clear difference between populations from Atlantic coasts and the Gulf of Mexico (Reeb and Avise, 1990), whereas data from allozyme and nuclear markers (e.g., MacDonald et al., 1996; Hare and Avise, 1996) and experimental reproduction (O'Foighil, pers. comm.) did not show any evidence of reproductive barriers. These two groups of $C$. virginica oysters have not been separated taxonomically. On the contrary, the distinction of three Mytilus species, described above, suggests to us that we should be cautious about the thorny topic of marine bivalve taxonomy and systematics. In this context, it remains difficult to determine the precise taxonomic classification of $C$. angulata and C. gigas. However, it can be noted that the existence of differentiated local populations of $C$. angulata and $C$. gigas still ordinarily reproductively compatible and mostly under conditions of allopatry is close to the subspecies concept. In the light of these results and to make a definitive statement on this topic, studies are needed to locate geographical zones where both taxa are in contact, and to document their level of natural hybridization in these zones

\section{Acknowledgements}

The authors wish to thanks Pr. D. O'Foighil (University of Michigan), Drs. C. Thiriot-Quiévreux (CNRS), S. Lapègue (IFREMER), H. McCombie (CNRS) and A. Leitão (U.T.A.D. of Vila Real/IFREMER) for their comments on the manuscript. The authors are also indebted to Dr. H. McCombie for helping with the translation of this manu- script. We thank F. Blouin for his technical help in making the crosses. We also thank F. Cornette and F. Rivet for providing oyster samples and all the staff of the Bouin IFREMER laboratory for raising the oysters. Part of this study was supported by the Conseil Général of CharenteMaritime and the Région Poitou-Charentes.

\section{References}

Alliegro, M.C., Wright, D.A., 1983. Polyspermy inhibition in the oyster, Crassostrea virginica. J. Exp. Zool. 227, 127-137.

Beaumont, A.R., Abdul-Matin, A.K.M., Seed, R., 1993. Early development, survival and growth in pure and hybrid larvae of Mytilus edulis and M. galloprovincialis. J. Moll. Stud. 59, 120-123.

Biene, N., David, P., Boudry, P., Bonbonne, F., in press. Assortative fertilization and selection at lorval stage in the mussels Mytilus edulis and M. galloprovincialis. Evolution.

Boudry, P., Heurtebise, S., Collet, B., Cornette, F., Gérard, A., 1998. Differentiation between populations of the Portuguese oyster, Crassostrea angulata (Lamark) and the Pacific oyster. Crassostrea gigas (Thunberg), revealed by mtDNA RFLP analysis. J. Exp. Mar. Biol. Ecol. 226, 279-291.

Bougrier, S., Raguenes, G., Bachère, E., Tigé, G., Grizel, H., 1986. Essai de réimplantation de Crassostrea angulata en France, Résistante au chambrage et comportement des hybrides Crassostrea angulataCrassostrea gigas. ICES, CMF 38, 10-10.

Buroker, N.E., Hershberger, W.K., Chew, K.K., 1979. Populations genetics of the family Ostreidae. I. Intraspecific studies of Crassostrea gigas and Saccostrea commercialis. Mar. Biol. 54, 157-169.

Cousteau, C., Renaud, F., Delay, B., 1991. Genetic characterization of the hybridization between Mytilus edulis and Mytilus galloprovincialis on the Atlantic coast of France. Mar. Biol. 111, 87-93.

Daguin, C., Bonhomme, F., Borsa, P., 2001. Mosaïcism in the European zone of sympatry and hybridization of Mytilus edulis and M. galloprovincialis, as revealed by intron length polymorphism at locus mac-1. Heredity 86, 342-354.

Desrosiers, R.R., Gérard, A., Peignon, J.M., Naciri, Y., Dufresne, L., Morasse, J., 1993. A novel method to produce triploids in bivalve molluscs by the use of 6-dimethyllaminopurine. J. Exp. Mar. Biol. Ecol. 170, 29-43.

Eversole, A.G., 1997. Gametogenesis of Mercenaria mercenaria, M. campechiensis and their hybrids. Nautilus 110, 107-110.

Gaffney, P.M., Allen, K.S., 1993. Hybridization among Crassostrea species: a review. Aquaculture 116, 1-13.

Gérard, A., 1998. Avancées récentes sur la reproduction des huîtres. Eur. Aquac. Soc. Spec. Publ. 26, 115-119.

Goulletquer, P., Wolowicz, M., Latala, A., Geairon, P., Huvet, A., Boudry, P., 1999. Comparative analysis of oxygen consumption rates between cupped oyster spat of Crassostrea gigas of French, Japanese, Spanish and Taiwanese origins. Aquat. Living Resour. 12, 271-277.

Grizel, H., Héral, M., 1991. Introduction into France of the Japanese oyster (Crassostrea gigas). J. Cons. Int. Explor. Mer. 47, 399-403.

Hare, M.P., Avise, J.C., 1996. Molecular genetic analysis of a stepped multilocus cline in the American oyster (Crassostrea virginica. Evolution 50, 2305-2315.

Héral, M., 1986. L'ostréiculture française traditionnelle. In: Barnabé, G (Ed.), Aquaculture, vol. 1. Tech. et Doc., Lavoisier, Paris, pp. 345-390.

Héral, M., Deslous-Paoli, J.M., Prou, J., 1986. Dynamiques des productions et des biomasses des huîtres creuses cultivées (Crassostrea angulata et Crassostrea gigas) dans le bassin de Marennes-Oléron depuis un siècle. ICES, CMF 41.

His, E., 1972. Premiers éléments de comparaison entre l'huître portugaise et l'huître japonaise. Pêche Marit. 219, 1-9. 
Huvet, A., Lapègue, S., Magoulas, A., Boudry, P., 2000. Mitochondrial and nuclear DNA phylogeography of Crassostrea angulata, the Portuguese oyster endangered in Europe. Cons. Genet. 1, 251-262.

Huvet, A., Balabaud, K., Bierne, N., Boudry, P., 2001. Microsatellite analysis of 6-hour-old embryos reveals no preferential intra-specific fertilization between cupped oysters Crassostrea gigas or Crassostrea angulata. Mar. Biotechnol. 3, 448-453.

Imai, T., Sakai, S., 1961. Study of breeding of Japanese oyster Crassostrea gigas. Tohoku J. Agric. Res. 12, 125-171.

Inoue, K., Odo, T., Noda, S., Nakao, S., Takeyama, E., Yamaha, E., et al., 1997. A possible hybrid zone in the Mytilus edulis complex in Japan revealed by PCR markers. Mar. Biol. 128, 91-95.

Koehn, R.K., 1991. The genetics and taxonomy of species in the genus Mytilus. Aquaculture 94, 125-145.

Leitão, A., Boudry, P., Labat, J.P., Thiriot-Quiévreux, C., 1999a. Comparative kariological study of cupped oyster species. Malacologia 41, 175-186.

Leitão, A., Thiriot-Quiévreux, C., Boudry, P., Malheiro, I., 1999b. A "G" chromosome banding study of three cupped oyster species: Crassostrea gigas, Crassostrea angulata and Crassostrea virginica (Mollusca: Bivalvia). Genet. Select. Evol. 31, 519-527.

Mathers, N.F., Wilkins, N.P., Walne, P.R., 1974. Phosphoglucose isomerase and esterase phenotypes in Crassostrea angulata and C. gigas. Biochem. Syst. Ecol. 2, 93-96.

Mattiucci, S., Villani, F., 1983. Studio elettroforetico dei sistemi geneenzima in ostriche classificate come Crassostrea gigas (Thunberg, 1793) e Crassostrea angulata (Lamarck, 1819) (Mollusca: Ostreidae). Parasitologia 25, 21-27.

Mayr, E., 1942. Systematics and the origin of species. Columbia University Press, New York.

Mayr, E., 1970. Populations, species and evolution. Belknap Press, Cambridge.

McCartney, M.A., Keller, G., Lessios, H.A., 2000. Dispersal barriers in tropical oceans speciation in Atlantic and eastern Pacific sea urchins of the genus Echinometra. Mol. Ecol. 9, 1391-1400.

McDonald, J.H., Verrelli, B.C., Geyer, L.B., 1996. Lack of geographic variation in anonymous nuclear polymophisms in the American oyster, Crassostrea virginica. Mol. Biol. Evol. 13, 1114-1118.

Menzel, R.W., 1968. Cytotaxonomy of species of clams (Mercenaria) and oysters (Crassostrea). Proc. Symp. Mollusca, part I. Mar. Biol. Assoc. India Ser., 3, pp. 75-86.
Menzel, R.W., 1971. Selective breeding in oysters. In: Price, K.S., Maurer, D.L (Eds.), Artificial Propagation of Commercially Valuable Shellfish. University of Delaware, New York, pp. 81-92.

Menzel, R.W., 1974. Portuguese and Japanese oysters are the same species. J. Fish. Res. Board Can. 31, 453-456.

Menzel, R.W., 1987. Hybridization in oysters and clams (1986). In: Tiews, K (Ed.), Selection, hybridization and genetic engineering in aquaculture. Heenemann GhBH \& Co., Berlin, pp. 47-59.

Numachi, K., 1966. Hybridization of oysters. Suisan Zoshoku 13, 126-129.

Numachi, K., 1977. Japanese species, breed and distribution. In: Imai, T (Ed.), Aquaculture in Shallow Seas: Progress in Shallow Sea Culture. Amerind Publishing Co., New Delhi, pp. 123-126.

O’Brien, S.J., Mayr, E., 1991. Bureaucratic mischief: recognizing endangered species and subspecies. Science 251, 1187-1188.

O'Foighil, D., Gaffney, P.M., Wilbur, A.E., Hilbish, T.J., 1998. Mitochondrial cytochrome oxidase I gene sequences support an Asian origin for the Portuguese oyster Crassostrea angulata. Mar. Biol. 131, 497-503.

Parache, A., 1989. Evolution de quelques paramètres de croissance des huîtres en élevage dans le bassin d'Arcachon de 1950 à 1986: Premiers résultats. Haliotis 19, 227-236.

Ranson, G., 1948. Ecologie et répartition géographique des Ostréidés vivants. Rev. Sci. 86, 469-473.

Reeb, C.A., Avise, J.C., 1990. A genetic discontinuity in a continuously distributed species: mitochondrial DNA in the American oyster, Crassostrea virginica. Genetics 124, 397-406.

Robert, R., Gérard, A., 1999. Bivalve hatchery technology: the current situation for the Pacific Oyster Crassostrea gigas and the scallop Pecten maximus in France. Aquat. Living Resour. 12, 121-130.

Rocha-Olivares, A., Fleeger, J.W., Foltz, D.W., 2001. Decoupling of molecular and morphological evolution in deep lineages of a meiobenthic harpacticoid copepod. Mol. Biol. Evol. 18, 1088-1102.

Sarver, S.K., Silberman, J.D., Walsh, P.J., 1998. Mitochondrial DNA sequence evidence supporting the recognition of the two subspecies or species of the Florida spiny lobster Panulirus argus. J. Crust. Biol. 18, 177-186.

Thiriot-Quiévreux, C., 1984. Analyse comparée des caryotypes d'Ostréidés (Bivalvia). Cah. Biol. Mar. 25, 407-418.

Walne, P.R., 1974. Culture of bivalve molluscs: fifty years experience at Conwy. Whitefriars Press Ltd, London. 